\title{
Meningkatkan Hasil Belajar Siswa Dengan Pembelajaran Berbasis Masalah
}

\section{Suparni}

SDN 21 Batang Anai Kabupaten Padang Pariaman

\begin{abstract}
Mathematics learning at 5th grade of SDN 21 Batang Anai Kabupaten Padang Pariaman indicated that learning process did not encourage students to apply the concepts in solving problems. It caused the students' learning achievement become low. This is a classroom action research aimed to improve students' learning achievement by implementing problem based learning (PBL). Data were obtained through observation and test. Mean of students' learning achievement from initial observation is 54.63 and become 72.78 in cycle I. Mean of students' learning achievement is 78.37 in cycle II. Hence, problem based learning can improve students' learning achievement.
\end{abstract}

Kata Kunci: learning achievement, PBL, mathematics

(i) This is an open access article distributed under the Creative Commons Attribution License, which permits unrestricted use, distribution, and reproduction in any medium, provided the original work is properly cited. (c)2017 by author and Indonesian Institute for Counseling, Education and Therapy (IICET)

\section{PENDAHULUAN}

Matematika adalah suatu ilmu yang berisi simbol-simbol, model, dan konsep-konsep yang berguna dalam kehidupan. Selain itu, matematika dapat membentuk pola pikir matematis yang sistematis, logis, kritis, dan perlu kecermatan. Bidang studi matematika berisi konsep-konsep yang dapat digunakan dalam segala aspek kehidupan yang dapat meningkatkan kemampuan berfikir yang logis dan memberikan kepuasan terhadap usaha memecahkan masalah dalam kehidupan sehari hari. oleh sebab itu di SD harus merancang pembelajaran yang membuat siswa memahami konsep matematika tersebut dan dapat menggunakannya dalam kehidupan. Agar pembelajaran matematika lebih bermakna bagi siswa, seharusnya dimulai dengan pemberian masalah yang terjadi dalam kehidupan siswa. Seperti dijelaskan oleh Depdiknas (2006) "pembelajaran matematika hendaknya dimulai dengan pengenalan masalah yang sering ditemui siswa dalam kehidupan sehari-hari". Hal tersebut berguna agar nantinya siswa mengetahui manfaat matematika tersebut dalam kehidupannya dan mereka dapat mengaplikasikan matematika dalam memecahkan masalah dalam kehidupan sehari-hari. Di dalam pembelajaran matematika, permasalahan dinyatakan dalam bentuk soal cerita . Seperti yang dikemukakan oleh Budhi (2006), soal cerita merupakan soal yang berbentuk cerita tentang sesuatu hal yang berkaitan dengan kehidupan sehari-hari.

Pembelajaran penyelesaian masalah dalam matematika perlu dilakukan secara sistematis dengan pemahaman konsep yang kuat oleh siswa. Hal tersebut tentu tidak lepas dari peran seorang guru yang merupakan faktor penting dalam pembelajaran. Guru harus mengetahui tugas yang harus dilakukannya dalam membelajarkan matematika agar pembelajaran tersebut menjadi lebih bermakna. Namun, penguasaan bahan saja tidak cukup, guru juga perlu menguasai strategi dan pendekatan pembelajaran matematika. Oleh sebab itu, guru harus dapat menciptakan iklim belajar yang kondusif dan dapat memilih strategi pembelajaran yang tepat. Dalam memilih strategi pembelajaran guru harus memperhatikan taraf perkembangan siswa secara baik, dengan 
mempertimbangkan karakteristik ilmu matematika dan siswa yang belajar. Siswa tingkat SD sedang mengalami perkembangan dalam tingkat berfikirnya. Siswa SD kelas rendah, taraf berfikirnya masih pada tahap konkret. Mereka masih kesulitan dalam mamahami konsep-konsep operasi seperti penjumlahan, pengurangan, pembagian, perkalian dan belum bisa diajak berfikir secara deduktif. Sedangkan siswa kelas tinggi (IV, V, VI, dengan usia 11 tahun ke atas) sudah berada pada tahap berfikir formal. Siswa sudah bisa berfikir secara deduktif. Oleh sebab itu, untuk mengembangkan pola pikir siswa tersebut guru perlu memilih strategi yang tepat dan sesuai dengan tahap perkembangan berfikir siswa dalam pembelajaran matematika. Ketepatan guru dalam memilih strategi pembelajaran akan berpengaruh terhadap hasil belajar siswa. Proses pembelajaran yang efektif akan meningkatkan hasil belajar yang dicapai siswa. Jadi, penggunaan strategi pembelajaran yang tepat menjadi salah satu penentu keberhasilan belajar.

Berdasarkan hasil pengalaman peneliti dalam proses pembelajaran di kelas Va SD 21 Batang Anai Kabupaten Padang Pariaman, ketika proses pembelajaran matematika tentang perkalian dan pembagian pecahan berlangsung, guru hanya mengarahkan siswa pada kemampuan menghapal konsep dan kemampuan siswa untuk menghafal informasi tanpa dituntut untuk memahami informasi yang diingatnya itu dan menghubungkan konsep yang didapatkan untuk menyelesaikan masalah dalam kehidupannya sehari-hari. Apabila siswa diberikan soal yang berupa pemahaman isian singkat, seperti yang peneliti lakukan misalnya $\frac{2}{5}: \frac{1}{5}=\cdots$ siswa berpacu untuk menyelesaikannya. Namun, setelah mereka diberikan masalah kontekstual berbentuk soal cerita yang terjadi dalam kehidupan sehari-hari yang penyelesaiannya memerlukan konsep, mereka menjadi kebingungan. Oleh karena itu, peneliti memakai strategi pembelajaran yang menuntut aktivitas mental siswa untuk lebih memahami suatu konsep pembelajaran melalui situasi dan masalah sehari-hari yang bertujuan untuk mengembangkan kemampuan berfikir dan mengembangkan kemampuan dalam memecahkan masalah, yaitu Pembelajaran Berbasis Masalah (PBM).

PBM menurut Wina (2008) adalah rangkaian proses pembelajaran yang menekankan kepada proses penyelesaian masalah yang dihadapi dalam kehidupan sehari-hari secara ilmiah. Senada dengan pendapat sebelumnya dikemukakan oleh Nurhadi (2003), PBM adalah suatu pendekatan pembelajaran yang menggunakan masalah dunia nyata sebagai suatu bahan bagi siswa untuk belajar bagaimana cara berfikir kritis, keterampilan pemecahan masalah dalam kehidupan, serta untuk memperoleh pengetahuan dan konsep yang esensial dari materi pembelajaran. Karakteristik PBM menurut Kunandar (2008), yaitu pengajuan pertanyaan atau masalah; terfokus pada keterkaitan antar disiplin; penyelidikan autentik; dan menghasilkan produk/karya dan memamerkannya.

PBM merupakan serangkaian aktivitas, dimana PBM tidak mengharapkan siswa hanya sekedar mendengarkan, mencatat, kemudian menghapal materi pelajaran. Akan tetapi, melalui PBM siswa aktif berfikir kreatif dan kritis yang memungkinkan siswa mempelajari masalah secara sistematis, berkomunikasi, mencari dan mengolah data, dan akhirnya menyimpulkan. Selain itu PBM mengarahkan pembelajaran untuk menyelesaikan masalah. Pembelajaran berpusat pada masalah. Dari masalah tersebutlah siswa belajar bagaimana untuk menyelesaikannya. Artinya, tanpa masalah tidak mungkin ada proses pembelajaran. PBM merupakan serangkaian pembelajaran yang menjadikan masalah sebagai bahan untuk pembelajaran. Pembelajaran dengan PBM memiliki beberapa tahapan atau langkah-langkah yang dilakukan untuk mencapai tujuan pembelajaran seperti yang dijelaskan oleh Nurhadi (2003): 1) mengorientasikan siswa pada masalah, 2) mengorganisasi siswa untuk belajar, 3) membimbing penyelidikan individual maupun kelompok, 4) mengembangkan dan menyajikan hasil karya, 5) menganalisis dan mengevaluasi proses pemecahan masalah.

\section{METODE}

Penelitian ini dilaksanakan di SDN 21 Batang Anai dengan pertimbangan peneliti mengajar pada SDN 21 Batang Anai dan di sini belum pernah dilakukan penelitian tindakan kelas tersebut. Penelitian dilakukan pada siswa kelas VA yang berjumlah 27 orang. Peneliti bertindak sebagai guru dan kepala sekolah sebagai observer. Penelitian ini adalah penelitian tindakan kelas yang terdiri 
dari perencanaa, pelaksanaan, pengamatan, dan refleksi. Data penelitian ini dikumpulkan dengan menggunakan observasi dan tes.

\section{HASIL}

\section{Deskripsi Siklus I}

\section{Perencanaan}

Tahap perencanaan terdiri dari persiapan RPP dan instrumen penelitian. Instrumen pengumpulan data yang digunakan adalah instrumen pengamatan keterlaksanaan RPP, lembar pengamatan aktivitas guru, lembar pengamatan aktivitas siswa, dan soal tes. Materi pembelajaran yang dilaksanakan adalah pembelajaran mengalikan bilangan asli dengan pecahan. Kompetensi dasar yang ingin dicapai pada materi ini yaitu mengali dan membagi berbagai bentuk pecahan. Indikator yang ingin dicapai adalah menyelesaikan masalah yang berhubungan dengan perkalian bilangan asli dengan pecahan.

\section{Pelaksanaan}

Pada pelaksanaan tindakan peneliti bertindak sebagai guru. Pelaksanaan terdiri dari beberapa tahapan pembelajaran berbasis masalah, yaitu tahap mengorientasikan siswa pada masalah, tahap mengorganisasikan siswa untuk belajar, tahap melakukan penyelidikan individual maupun kelompok, dan tahap mengembangkan dan menghasilkan hasil karya. Mengakhiri kegiatan, guru membimbing siswa merangkum materi pelajaran dan memberikan tes kepada masing-masing individual siswa.

\section{Pengamatan}

Pembelajaran pada siklus I ini diamati oleh kepala sekolah. Sedangkan proses pembelajarannya dilaksanakan oleh peneliti sendiri sebagai guru. Pengamatan yang dilakukan observer mengenai aktivitas guru dan siswa dilakukan dengan mencatat sesuai yang terdapat pada lembar pengamatan. Siswa terlihat masih malu-malu maju ke depan untuk mengerjakan soal dan masih menjawab secara klasikal pertanyaan-pertanyaan guru. Setelah itu, guru menyampaikan tujuan pembelajaran yang akan dipelajari, yaitu mengalikan bilangan asli dengan pecahan. Tapi ada sebahagian siswa yang kurang mendengarkan guru dalam menyampaikan tujuan pembelajaran.

\section{Refleksi}

Kegiatan refleksi dilakukan secara kolaboratif antara observer dengan peneliti. Refleksi tindakan siklus I ini mencakup refleksi terhadap perencanaan, pelaksanaan, dan hasil belajar yang diperoleh oleh siswa. Penyajian materi dengan menggunakan PBM sudah sesuai dengan rencana namun waktu yang digunakan untuk berdiskusi pada siklus I terlalu panjang sehingga waktu untuk melaksanakan tes sedikit, sehingga siswa terburu-buru mengerjakan soal. Pada saat diskusi terdapat beberapa pertanyaan guru yang kurang dipahami oleh siswa, sehingga ada beberapa kelompok yang kurang memahami permasalahan yang didiskusikan. Masih banyak siswa yang belum aktif terlibat dalam pembelajaran khususnya sewaktu melakukan diskusi hanya didominasi oleh beberapa orang siswa saja.

Siswa kesulitan dalam pengisian LKS, hal ini disebabkan karena siswa kurang mengerti dalam penggunaan media. Untuk itu peneliti perlu memberikan penjelasan tentang penggunaan media. Masih ada 3 kelompok yang kesulitan mengaplikasikan kegiatan konkret ke semi konkrit. Hasil tes siklus I menunjukkan belum keseluruhan siswa memahami materi yang diberikan. Masih ada beberapa siswa yang masih mendapatkan nilai tes di bawah ratarata. Setelah ditanyakan kepada siswa ternyata beberapa dari mereka tidak memahami permasalahan disamping itu mereka tidak terlalu konsentrasi karena didesak waktu oleh guru. Berdasarkan pengamatan dan tes, tujuan pembelajaran yang diharapkan pada pembelajaran siklus I belum tercapai dengan baik terdapat 9 orang anak yang belum mencapai ketuntasan belajar yang telah ditetapkan. Dengan demikian pembelajaran penyelesaian masalah dengan menggunakan PBM dilanjutkan pada siklus II.

\section{Deskripsi Siklus II}




\section{Perencanaan}

Agar peneliti dapat melaksanakan tugas dengan baik, maka peneliti menyiapkan rencana pelaksanaan pembelajaran, lembar pengamatan aktivitas guru dan siswa dalam pembelajaran, serta soal tes. Dalam membuat perencanaan siklus II, peneliti menggunakan hasil yang diperoleh dari refleksi pada siklus I.

\section{Pelaksanaan}

Pelaksanaan pembelajaran pertemuan II ini sesuai dengan rencana yang telah ditetapkan. Mengawali tindakan, peneliti mengucapkan salam. Kemudian menyiapkan kondisi kelas, menyuruh siswa berdoa serta mencek kehadiran siswa, menyampaikan topik yang akan dipelajari yaitu membagi pecahan dengan pecahan. Barulah guru menyampaikan tujuan pembelajaran. Pada kegiatan inti, tahap mengorientasikan siswa pada masalah. Kemudian guru melakukan tanya jawab dengan siswa tentang permasalahan tersebut. dan siswapun menjawab pertanyaan yang diberikan guru. Pada tahap mengorganisasikan siswa untuk belajar kegiatan, guru membagi siswa menjadi 5 kelompok. Pada tiap-tiap anggota kelompok, guru memberikan alat dan bahan yang diperlukan untuk menyelesaikan masalah, yaitu 1 buah kertas karton. Setelah itu guru meminta masing-masing kelompok membaca LKS dan bertanya apabila ada keraguan dalam LKS. Pada tahap ini, siswa menerima alat dan bahan yang diberikan guru.

Kemudian pembelajaran dilanjutkan dengan tahap melakukan penyelidikan individual maupun kelompok. Dengan menggunakan alat dan bahan yang telah diberikan tersebut, siswa melakukan penyelidikan dengan menciptakan suasana seperti dalam masalah, yaitu dengan mengikuti langkah-langkah yang terdapat dalam LKS. Tahap mengembangkan dan menghasilkan hasil karya, kegiatan yang dilakukan guru yaitu membimbing siswa membuat model dan mengisi LKS. Setelah selesai berdiskusi, guru meminta masing- masing kelompok melaporkan hasil diskusi ke depan kelas. Tahap terakhir yaitu tahap menganalisis dan mengevaluasi proses pemecahan masalah guru meminta kelompok lain menanggapi hasil diskusi kelompok lain. Kemudian bersama-sama mengevaluasi hasil pemecahan masalah yang telah didiskusikan. Mengakhiri kegiatan, guru membimbing siswa merangkum materi pelajaran dan memberikan tes kepada masing-masing individual siswa.

\section{Pengamatan}

Keberhasilan guru dalam pelaksanaan tindakan mencapai keberhasilan sangat baik, dengan skor yang diperoleh 57. Keberhasilan aktivitas siswa dalam pembelajaran mencapai keberhasilan sangat baik dengan perolehan skor 56 . Hasil belajar siswa pada pertemuan II mencapai nilai rata-rata 78,37 .

\section{Refleksi}

Kegiatan refleksi dilakukan secara kolaboratif antara peneliti dengan kepala sekolah. Refleksi tindakan siklus II ini mencakup refleksi terhadap perencanaan, pelaksanaan, dan hasil belajar yang diperoleh oleh siswa. Hasil belajar siswa pada siklus II ini meningkat dibandingkan dengan hasil belajar pada siklus I dengan perbandingan 72,78 pada siklus I dan pada siklus II meningkat menjadi 78,37. Hasil belajar siswa pada siklus II tersebut telah mencapai standar ketuntasan yang telah ditetapkan sekolah yaitu 75. Jadi, dapat disimpulkan bahwa peneliti dalam pembelajaran siklus II telah melaksanakan tugas dengan baik. Dengan demikian, penelitian ini berhenti pada siklus II. Penyajian materi dengan menggunakan PBM sudah sesuai dengan rencana dan waktu yang digunakan untuk berdiskusi sudah dapat dimanfaatkan siswa dengan baik. Dalam berdiskusi $75 \%$ siswa sudah aktif menjawab dan bertanya, dan bekerja dalam kelompok. Kelompok terlihat sudah tidak kesulitan mengaplikasikan kegiatan konkret ke semi konkrit. Hasil tes siklus I menunjukkan siswa sudah memahami materi yang diberikan. Sudah $75 \%$ siswa yang tuntas dalam belajar. Walaupun masih ada beberapa siswa yang masih mendapatkan nilai tes di bawah rata-rata.

\section{PEMBAHASAN}

\section{Siklus I}


Perencanaan yang dibuat pada siklus I sudah baik. Terlihat dari penilaian perencanaan yang telah dinilai oleh pengamat mencapai keberhasilan baik. Pelaksanaan pembelajaran yang aktif dan menyenangkan sangat dibutuhkan oleh siswa Sekolah Dasar, pembelajaran yang menyenangkan. Di dalam kelompok siswa saling tolong menolong, dan siswa dapat dengan mudah memahami materi pelajaran, sesuai dengan rencana pembelajaran berbasis masalah yang dirancang sendiri oleh peneliti. Penyajian materi dengan menggunakan PBM sudah sesuai dengan rencana namun waktu yang digunakan untuk berdiskusi siklus 1 terlalu panjang sehingga waktu untuk melaksanakan tes sedikit, sehingga siswa terburu-buru mengerjakan soal. Kurangnya rasa tangung jawab di dalam diskusi. Dalam kelompok hanya beberapa orang siswa saja yang ikut bekerja, sedangkan yang lainnya hanya duduk karena guru kurang memberikan motivasi kepada siswa untuk bekerjasama dalam kelompok sehingga siswa yang ikut menulis saja yang aktif.

Pada saat diskusi terdapat beberapa pertanyaan guru yang kurang dipahami oleh siswa sehingga ada beberapa kelompok yang kurang memahami permasalahan yang didiskusikan. Masih banyak siswa yang belum aktif terlibat dalam pembelajaran khususnya sewaktu melakukan diskusi hanya didominasi oleh $50 \%$ orang siswa saja dan yang aktif menjawab pertanyaan hanya sebahagian kecil saja. Masih ada 3 kelompok yang kesulitan mengaplikasikan kegiatan konkret ke semi konkrit. Hasil tes siklus I menunjukkan belum keseluruhan siswa memahami materi yang diberikan. Masih ada beberapa siswa yang masih mendapatkan nilai tes di bawah rata-rata. Setelah ditanyakan kepada siswa ternyata banyak yang menjawab soal yang diberikan guru sulit dan mereka tidak memahami permasalahan disamping itu mereka tidak terlalu konsentrasi karena didesak waktu oleh guru. Pelaksanaan tindakan pada siklus I pada aspek guru mencapai keberhasilan baik dan pada aktivitas siswa mencapai keberhasilan baik. Nilai rata-rata hasil belajar siswa pada pertemuan I yaitu 72,78. Namun, masih ada 9 orang siswa yang memperoleh nilai dibawah rata-rata. Hasil belajar tersebut mengalami peningkatan dibanding hasil belajar sebelum menggunakan strategi pembelajaran berbasis masalah akan tetapi hasil belajar siswa tersebut hanya mencapai ketuntasan belajar, yaitu 75 .

\section{Siklus II}

Perencanaan tindakan pada siklus 2 mencapai keberhasilan baik. Seperti tergambar dalam format penilaian RPP yang diisi oleh pengamat. Pada pelaksanaan tindakan sesuai dengan perencanaan. Penyajian materi dengan menggunakan PBM sudah sesuai dengan rencana yang telah dibuat dan waktu yang digunakan untuk berdiskusi sudah dapat dimanfaatkan siswa dengan baik. Guru sudah baik dalam memotivasi siswa untuk bekerjasama dalam diskusi dan sudah memberikan penghargaan kepada setiap jawaban-jawaban siswa sehingga siswa bersemangat untuk belajar. Dalam berdiskusi, 75\% siswa sudah aktif manjawab, bertanya, dan bekerja dalam kelompok. Kelompok terlihat sudah tidak kesulitan dalam mengisi LKS. Hasil tes siklus I menunjukkan siswa sudah memahami materi yang diberikan. Sudah $75 \%$ siswa yang tuntas dalam belajar. Walaupun masih ada beberapa siswa yang masih mendapatkan nilai tes di bawah rata-rata. Pada tahap pelaksanaan tindakan pada aspek guru sesuai dengan hasil pengamatan observer mencapai keberhasilan baik dan aspek siswa mencapai keberhasilan baik. Hasil belajar siswa pada siklus II mencapai nilai rata-rata 78,37. Pada siklus II, yaitu guru dalam memberikan motivasi sangat bagus. Pada proses pembelajaran guru banyak memberikan kesempatan kepada siswa untuk berdiskusi bersama dan bertanya tentang permasalahan yang tidak dimengerti oleh siswa. Guru membimbing siswa dengan baik. Guru mampu menciptakan situasi yang menyenangkan untuk belajar sehingga hasil belajar siswa meningkat.

\section{KESIMPULAN}

Perencanaan pembelajaran dengan menggunakan pembelajaran berbasis masalah disesuaikan dengan langkah-langkahnya, yaitu mengorientasikan siswa pada masalah, mengorganisasikan siswa untuk belajar, membimbing penyelidikan individual dan kelompok, mengembangkan dan menyajikan hasil karya, dan menganalisa dan mengevaluasi proses pemecahan masalah. Pelaksanaan pembelajaran dengan PBL dapat membuat siswa lebih aktif dalam belajar. siswa diajarkan untuk berdiskusi dalam memecahkan masalah, siswa dibimbing bekerjasama dalam kelompok. Sehingga pembelajaran lebih bermanfaat bagi siswa. Siswa dibimbing untuk menyelesaikan masalah secara sistematis. Keberhasilan aktivitas guru pada pembelajaran perkalian 
pecahan melalui strategi pembelajaran berbasis masalah pada siklus 1 mencapai keberhasilan baik dan aktivitas siswa mencapai keberhasilan baik.

\section{SARAN}

Pada siklus 2, aktifitas guru mencapai keberhasilan sangat baik dan aktivitas siswa mencapai keberhasilan sangat baik. Meningkatnya hasil belajar siswa dapat dilihat dari hasil belajar siswa sebelum tindakan, yaitu 54,63 meningkat pada siklus I menjadi 72,02. Pembelajaran belum dianggap tuntas jika hasil yang diperoleh di bawah $75 \%$ dan untuk itu penelitian ini dilanjutkan pada siklus II dan hasil belajar pada siklus II mengalami peningkatan menjadi 78,37. Untuk guru, agar dapat mencobakan dan menerapkan Strategi Pembelajaran yang lebih bervariasi dengan tujuan agar siswa dapat tertarik untuk mengikuti pelajaran yang diberikan. Bagi kepala sekolah dapat menganjurkan kepada guru untuk menerapkan bentuk pembelajaran ini, pada kelas yang lain.

\section{DAFTAR RUJUKAN}

Dalais, Mursal. (2007). Kiat Mengajar Matematika di Sekolah Dasar. Padang: UNP Press.

Depdiknas. (2006). Kurikulum Tingkat Satuan Pendidikan (KTSP). Jakarta: Depdiknas.

Kunandar. (2007). Guru Profesional Implementasi Kurikulum Tingkat Satuan Pendidikan (KTSP) dan Sukses dalam Sertifikasi Guru. Jakarta: Raja Grafindo Persada.

Nurhadi dan Agus G.S. (2003). Pembelajaran Kontekstual (Contectual Teaching Learning/ CTL) dan Penerapannya dalam KBK. Malang: UM Press.

Sanjaya, Wina. (2008). Strategi Pembelajaran Berorientasi Standar Proses Pendidikan. Jakarta: Kencana Prenada Media Group.

Sudjana, Nana. (2002). Dasar-Dasar Proses Belajar Mengajar. Bandung: Sinar Baru Algesindo. 